\title{
Interleukin-6-Mediated Cell Growth in Multiple Myeloma - a Role for Viscum album Extracts?
}

\author{
Michael Hallek \\ Klinik I für Innere Medizin der Universität zu KöIn, Germany
}

Interleukin-6 (IL-6) is a major growth factor for lymphoma and multiple myeloma cells in vitro and in vivo $[1,2]$. Despite strong evidence for a role of IL-6 in the pathogenesis of lymphoid malignancies, the signaling mechanisms responsible for IL-6-mediated cell growth are not fully understood. To exert its biological effects, IL-6 must bind to the IL-6 receptor (IL$6 \mathrm{R}$ ), composed of two $\alpha$-chains (IL-6R $\alpha, 80 \mathrm{kDa}$ ) and two $\beta$ chains (IL-6R $\beta$ or gp130, $130 \mathrm{kDa}$ ) [2, 3]. Two moieties of IL-6 and two pairs of these receptor chains form a functional hexameric IL-6R complex. The subsequent intracellular signaling events are activated via gp130 which is the common $\beta$ chain of the receptors for cardiotrophin-1 (CT-1), ciliary neurotrophic factor (CNTF), oncostatin M (OSM), leukemia inhibitory factor (LIF), interleukin-11 (IL-11) and IL-6. Activation of the IL-6R stimulates at least two major signaling pathways, the Src homology 2 (SH2) domain containing protein tyrosine phosphatase 2 (Shp-2) / mitogen activated protein kinase (MAPK) signaling cascade, and the Janus kinase (Jak) / signal transducer and activator of transcription (STAT) pathway [3]. It was shown that gp130-mediated signals were regulated by a balance between these two pathways. In addition, the activation of Src kinases might play an important role as well [4]. It is known that some lymphoid cells, most notably multiple myeloma cells secrete IL-6 in an autocrine or paracrine manner [1]. This effect has been used to explain the factor-dependent growth of some multiple myeloma cell lines when cultured in vitro.

The paper by Hugo and colleagues in this issue of ONKOLOGIE [5] examines the influence of an extract from Viscum album (Iscador $\mathrm{P}^{\circledR}$ ) on the IL-6 secretion in some non-Hodgkin's lymphoma (NHL) cell lines. The results obtained are essentially negative. It is shown that the expression of IL-6 and its receptor were not changed upon stimulation with the plant ex- tract, both on the protein level and on the mRNA level (as shown by real time-RT-PCR).

What can we learn from these studies? - Very little. First, it is not particularly surprising to see that lymphoid tumor cells do not respond when stimulated with a multi-component plant extract. Second, the read-out system (IL-6 and IL-6 receptor expression) is only one pair out of dozens of ligand/receptor interactions that may influence the fate of neoplastic lymphoid cells. Third, only cell lines were used for these studies, further reducing the relevance of these observations. Finally, no effort was undertaken to study the actions of Iscador on cell proliferation, apoptosis or other functional parameters. Therefore, the results presented in the paper of Hugo and colleagues do not even allow to conclude that Iscador has no effect on the IL-6 secretion of lymphoid malignancies. Thus, while the effort to study the effects of complementary medicines on the cellular level deserves credit, more systematic functional analyses are warranted in the future to learn more about the potential stimulation of malignant cell proliferation in NHL by $V$. album extracts.

\section{References}

1 Hallek M, Bergsagel LP, Anderson K: Multiple myeloma: increasing evidence for a multistep transformation process. Blood 1998;91:3-21.

2 Akira S, Taga T, Kishimoto T: Interleukin-6 in biology and medicine. Adv Immunol 1993;54:1-78.

3 Kishimoto T. Interleukin-6: from basic science to medicine-40 years in immunology. Annu Rev Immunol 2005;23:1-21.

4 Schäffer M, Schneiderbauer M, Weidler S, Tavares R, Warmuth M, de Vos G, Hallek M: Signaling through a novel domain of gp130 mediates cell proliferation and activation of Hck and Erk kinases. Mol Cell Biol 2001;21:8068-8081.

5 Hugo F, Dittmar T, Treutler EK, Zänker KS, Kuehn JJ: The viscum album extract iscador $\mathrm{p}$ does not cause an autocrine interleukin-6 loop in b-non-Hodgkin's lymphoma cell lines. Onkologie 2005;28:415-420.

\begin{tabular}{ll}
\hline KARGER & @ 2005 S. Karger GmbH, Freiburg \\
Fax +4976145207 14 & Accessible online at: \\
$\begin{array}{l}\text { E-mail Information@Karger.de } \\
\text { www.karger.com }\end{array}$ & www.karger.com/onk
\end{tabular}

